\title{
MELTING AND HEAT EXCHANGE AT THE BOTTOM OF A SNOW COVER
}

\author{
by
}

\section{Kenji KoJma and Hideaki Motoyama}

Institute of Low Temperature Science, Hokkaido University, Nishi 8, Kita 19, Kita-ku, Sapporo, Japan

\section{ABSTRACT}

The melting rate of the bottom of a snow cover during the winter and its variation with time were studied in relation to heat exchange at the ground-snow interface. Continuous observations were made of bottom-melt, using a lysimeter, during the past four winters beginning December 1980, at our test field in Moshiri, Hokkaido, which is known for severe coldness and deep snow.

During the four months in this area the amount of bottom-melt ranged from $45-70 \mathrm{~mm}$ in total and from $0.4-0.6 \mathrm{~mm}$ per day on average. In winters with much snow the daily amount of bottom-melt decreased gradually from a maximum of about $1.5 \mathrm{~mm} \cdot \mathrm{d}^{-1}$ in early December, reached its minimum of $0.2-0.3 \mathrm{~mm} \cdot \mathrm{d}^{-1}$ day in February, and then increased again. In a winter with a smaller amount of snow it varied greatly with time during the early period of the winter and became zero temporarily. Such variations of the melting rate could be explained by conductive heat fluxes observed in the ground and snow. The daily average of the former was about $5 \mathrm{~W} \cdot \mathrm{m}^{-2}$ at a depth of $0.1 \mathrm{~m}$ in early December and decreased to about $2.5 \mathrm{~W} \cdot \mathrm{m}^{-2}$ in early April.

\section{INTRODUCTION}

The rate of melting at the bottom of a snow cover during the winter is fairly small, compared with that of surface melting in spring. It plays, however, an important role since it provides a continuous supply of water to the ground under deep snow in winter, delays ablation of an artificially compressed snow cover (Fujii and Kojima 1974), and causes an increase in settling force of snow acting on a structure or tree buried in deep snow (Ishikawa and others 1978). Accordingly, since the end of 1980 observations have been made of the daily amount of bottom-melt of a snow cover throughout the winter, its monthly variation from December to April, and its yearly variation. The observations were made in Moshiri, Hokkaido which is known for severe coldness and deep snow. Under such conditions meltwater produced in this area by occasional surface melting does not reach the bottom of the snow cover during the coldest season. Then, the amount of water melted at the bottom, which occurs throughout almost every winter, can be measured separately except in the early and late winter periods.

\section{METHOD}

A shallow lysimeter, $90 \times 90 \mathrm{~cm}$ wide and $10 \mathrm{~cm}$ deep at its center, was installed on top of the level ground in front of Snow Melting Research Station in Moshiri so that it came to be buried at the bottom of a snow cover. Meltwater which had percolated into the lysimeter was led to a rain gauge set at the basement of the station through a plastic tube $14 \mathrm{~m}$ in length and the amount was recorded continuously. For this measurement another lysimeter was installed in the vicinity; data from the two were averaged. The amount of conductive heat flux in the ground and that in the snow cover were also continuously recorded. One of the two sensors for measuring heat flow was buried at a depth of $10 \mathrm{~cm}$ in the ground and the other was set in the snow cover at a height corresponding to a water equivalent of about $70 \mathrm{~mm}$, which approximates to the total amount of bottom-melt during the winter in the test area. A sketch of instrumentation was previously reported by Kojima (1980).

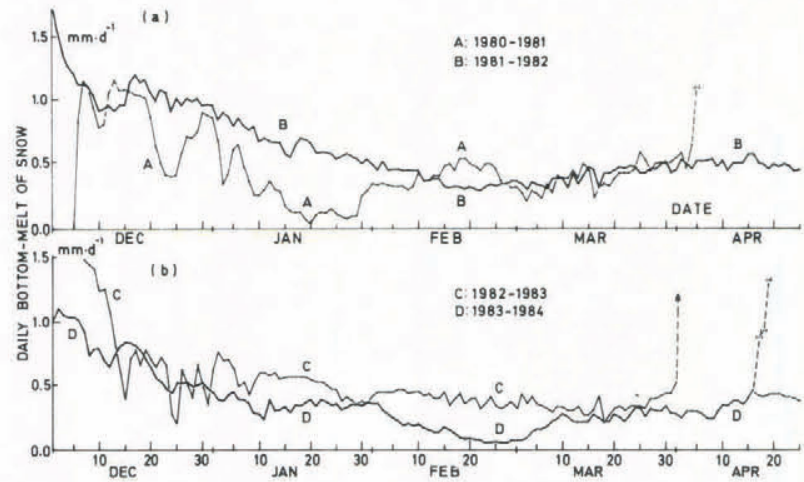

Fig.1. Daily amount of bottom-melt of a snow cover in $\mathrm{mm}$-water $\cdot \mathrm{d}^{-1}$ observed by a lysimeter. Rapidly increasing dashed lines show the discharge of water due to surface-melt.

\section{RESULTS}

Time variations of the amount of daily bottom-melt in $\mathrm{mm} \cdot \mathrm{d}^{-1}$ of water or $\mathrm{kg} \cdot \mathrm{m}^{-2} \cdot \mathrm{d}^{-1}$ during the four winters beginning December 1980, named A, B, C, and D, are shown in Figure 1. The area had much snow in winter B, when the monthly average of snow depth was $2.0 \mathrm{~m}$ in January and $2.3 \mathrm{~m}$ in February, 1982. On the contrary, in the previous winter accumulation was unusually small, averaging $0.85 \mathrm{~m}$ in January and $1.24 \mathrm{~m}$ in February. The monthly average air temperatures in January and February were -14.7 and $-13.0^{\circ} \mathrm{C}$ in $1981 ;-12.4$ and $-14.6^{\circ} \mathrm{C}$ in 1982. In the winter with much snow the daily amount of bottom-melt decreased gradually from the highest value of about $1.5 \mathrm{~mm} \cdot \mathrm{d}^{-1}$ in the early period of the winter. It reached the minimum of $0.2-0.3 \mathrm{~mm} \cdot \mathrm{d}^{-1}$ after

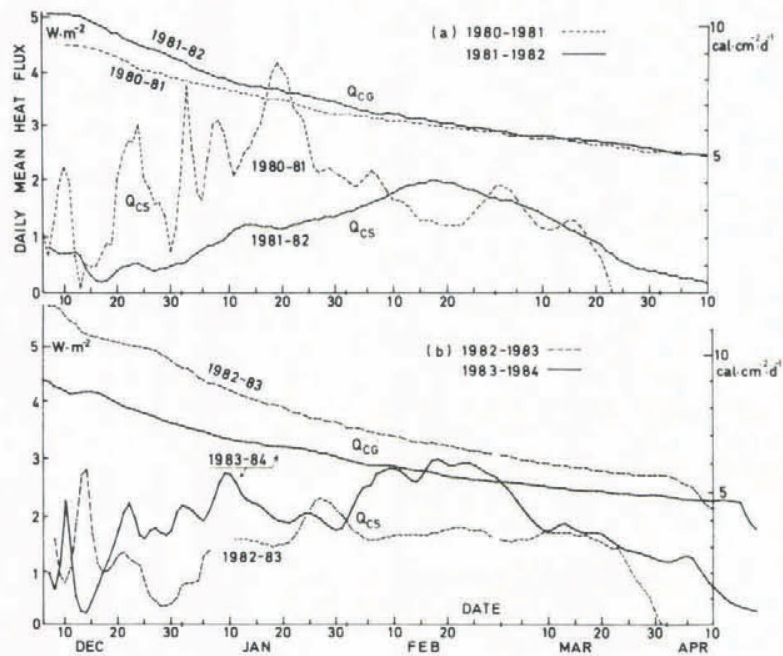

Fig.2. Daily mean upward heat flux in the ground, $\mathrm{Q}_{\mathrm{CG}}$, and that in the snow cover, $\mathrm{Q}_{\mathrm{CS}}$, in $\mathrm{W} \cdot \mathrm{m}^{-2}$. 
mid-February and then increased again toward the surface-melting season. The amount of bottom-melt in winter A varied greatly with time during the early period of the winter and approached zero on 20 January. Generally during the four months beginning in December the amount of bottom-melt in this area ranges from $45-70 \mathrm{~mm}$ in total and from $0.4-0.6 \mathrm{~mm} \cdot \mathrm{d}^{-1}$ on the average.

The daily mean upward heat flux in the ground, $Q_{C G}$, is generally greater than that in the snow cover, $Q_{C S}$, as seen in Figure 2. Let the flux difference, $Q_{C G}-Q_{C S}$, be divided by the latent heat of the ice melting $L_{m}$; then $\left(\mathrm{Q}_{\mathrm{CG}}-\mathrm{Q}_{\mathrm{CS}}\right) / \mathrm{L}$ gives the approximate amount of bottom-melt. The time variations of its daily value explain well the time variations of bottom-melt observed by the lysimeter with some exceptions, as seen by comparing Figure 3 with Figure 1. The variation of $Q_{C S}$ is greatly influenced by the snow-depth in relation with the profile of snow temperatures (Figure $4 a$ ), while the flux $Q_{C G}$ varies in almost the same manner every winter. However, the clear
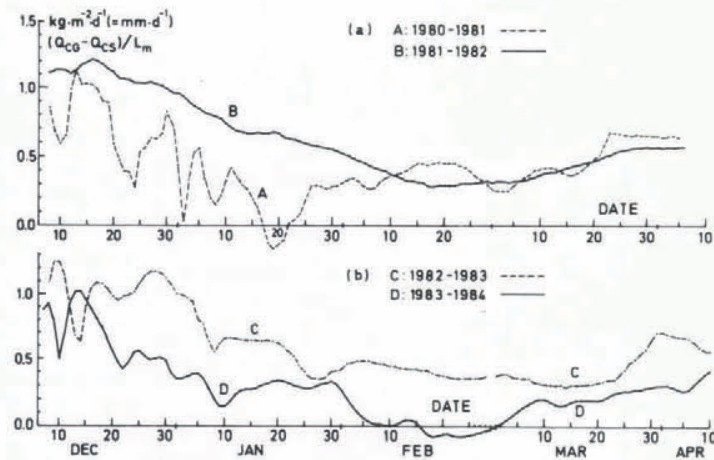

Fig.3. Variation in the amount of daily bottom-melt estimated from the difference between the heat flux in the ground and that in the snow cover, $Q_{C G}-Q_{c s}$ $\left(\mathrm{kJ} \cdot \mathrm{m}^{-2} \cdot \mathrm{d}^{-1}\right)$, divided by the latent heat of ice mleting $\mathrm{L}_{\mathrm{m}}\left(\mathrm{kJ} \cdot \mathrm{kg}^{-1}\right)$. difference in $Q_{C G}$ in two winters $C$ and $D$, shown in Figure $2 b$, is due to the difference in the climate of the preceding summers; comparatively hot and sunny in 1982 and unusually cool in 1983. The amount of downward heat flux (Figure 4b) integrated from May to the end of August 1982 , was greater than that of next summer by $24 \%$. An unusually small heat storage in the ground in the cool summer of 1983 was reflected in the small amount of bottom-melt in winter $\mathrm{D}$.

Where the ratio of 20-year monthly mean air temperature to snow depth in January or February is much greater than $10^{\circ} \mathrm{C} / \mathrm{m}$, the ground is frozen; bottom-melt of snow may not occur for much of the time in these months in Hokkaido.

\section{DISCUSSION}

A plot of the daily bottom-melt $P_{L}$ observed by lysimeters against the bottom-melt $P_{H}$ estimated from heat flow shows approximately a linear relation between them with a correlation coefficient of nearly 0.95 for most periods in a winter excluding a period with extremely small values of $P_{H}$ such as February 1984. The most remarkable discrepancy between $\mathrm{P}_{\mathrm{L}}$ and $\mathrm{P}_{\mathrm{H}}$ appeared during the three weeks from 15 December 1982. This was probably caused by reduced rates in discharge of meltwater due to trouble in the drainage system of one lysimeter, which led to our underestimating the bottom-melt during that period.

\section{REFERENCES}

Fujii T, Kojima K 1974 [Delay in ablation of artificially packed part of snow cover.] Low Temperature Science A 32: 129-141 (in Japanese with English summary)

Ishikawa M, Ono S, Kawaguchi T 1978 [Effect of heat from the ground upon subsidence force of snow.] Seppyo (Journal of the Japanese Society of Snow and Ice) 4(1): 47-49 (in Japanese)

Kojima K 1980 [Continuousobservation of melting at the bottom of a snow cover during the winter (Preliminary report).] Low Temperature Science A 39: 101-108 (in Japanese with English summary)
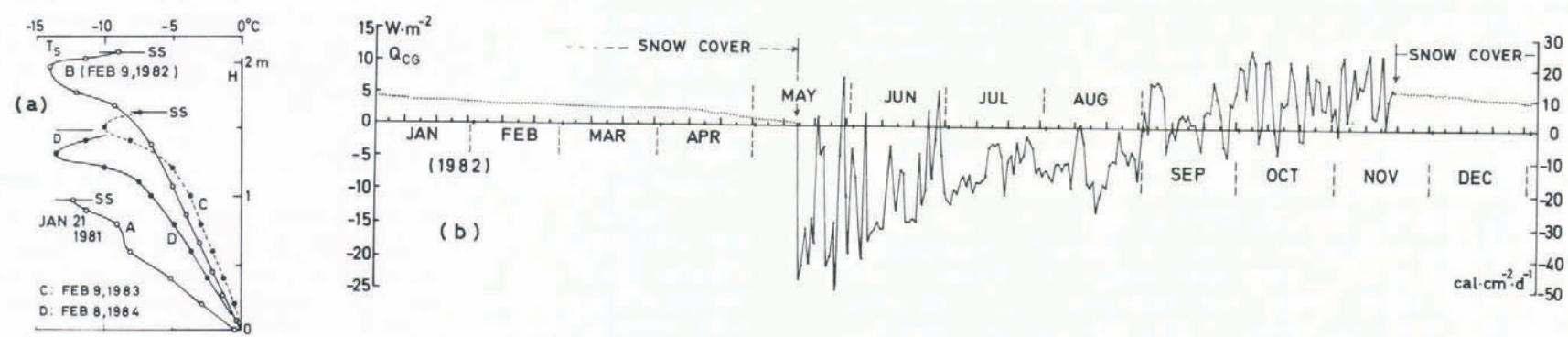

Fig.4. (a) Profiles of snow temperature $\mathrm{T}_{\mathrm{S}}\left({ }^{\circ} \mathrm{C}\right)$ in or around the coldest period of each winter. (b) Daily mean upward heat flux in the ground at a depth of $0.1 \mathrm{~m}$, showing its variation throughout 1982. A negative value shows a downward heat flux as a daily net amount. 